International Journal of Social Science and Economic Research

ISSN: 2455-8834

Volume:05, Issue:11 "November 2020"

\title{
RESEARCH ON THE INFLUENCE OF FAMILY RESOURCES ON CHILDREN'S COGNITIVE ABILITY
}

\author{
Hao-jian Dui \\ School of Labor and Economics, Capital University of Economics and Business, Beijing, China \\ DOI: 10.46609/IJSSER.2020.v05i11.001 URL: https://doi.org/10.46609/IJSSER.2020.v05i11.001
}

\begin{abstract}
Children's cognitive abilities are of great significance to their future development, and family is the most important environmental factor in children's growth. This article analyzes the impact of family resources on children's cognitive abilities based on the data from CFPS2016. The empirical results show that family economic resources have no significant impact on children's cognitive abilities. On the contrary, family non-economic resources have significant effects on children's cognitive abilities, especially parents' cognitive abilities, academic expectations and family environment. Moreover, under the premise of controlling the family's non-economic resources, education expenditure has a certain effect on improving the cognitive ability of lower grade students. Based on the conclusions, this article puts forward the following recommendations: First, parents should encourage children to study knowledge and correct life attitudes; second, parents need to increase communication with their children; finally, efforts should be made to reduce the education gap between urban and rural areas and pay more attention to the physical and mental health of girls.
\end{abstract}

Keywords: family resources; children; cognitive ability

\section{Introduction}

Children's cognitive ability have important influence on their future health ${ }^{[i][i][i i i]}$ (Batty et al., 2005; Chandola et al., 2006; Batty et al., 2007)、 socioeconomic status ${ }^{[i v][v][v i]}$ (Thienpont \& Verleye, 2004; Irwing \& Lynn, 2006; Wang \& Wang, 2016) and other aspects. According to existing research, the influencing factors of children's cognitive ability mainly include genetic

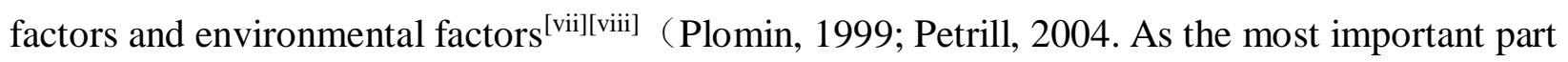
of children's environment, the family ${ }^{[i x]}$ (Harris, 2011, the influence of it on children's cognitive ability has aroused widespread concern in academia. Among them, the most widely accepted view is that the economic status of the family is an important factor affecting children's 
International Journal of Social Science and Economic Research

ISSN: 2455-8834

Volume:05, Issue:11 "November 2020"

cognitive development ${ }^{[x][x i][x i i]}$ (Gagné, 2003; Schoon et al., 2012; Khanam R, Nghiem S, 2016). However, some scholars believe that economic factors such as family income cannot directly affect the development of children's cognitive ability, on the contrary, the non-economic characteristics of the family are more important ${ }^{[\mathrm{xiii}][\mathrm{xiv}]}$ (Blau, 1999; Violato et al.,2011). Based on these, this article divides family resources into economic resources and non-economic resources, and further studies the impact of family on children's cognitive abilities.

\section{Theoretical Basis}

\subsection{Human Capital Theory}

Since the creation of the human capital theory in the 1960s, many scholars have been deeply involved in this, making its connotation gradually enriched, and measurement methods are constantly developing. ${ }^{[\mathrm{x}][\mathrm{xvi}]}$ Among them, Becker, the Nobel laureate in economics, pioneered a microeconomic analysis of human capital. He emphasized the importance of human capital investment in education and training. In 1964, he pointed out that the advantages of some children are mainly derived from their stronger birth ability, more emphasis on children's learning, and other favorable genetic and cultural attributes in families in his book "Human Capital". Physiological and cultural traits are passed on to children by parents. The former is through DNA, and the latter is through family culture ${ }^{[x v i]}$.

The advantage that Becker refers to in the article is reflected in a higher level of human capital. Moreover, the human capital theory believes that human capital investment is the main way to improve the level of human capital. Considering economic factors, in a family's budget constraints, the human capital investment made by the parent to the offspring is usually limited by the level of family income ${ }^{[x v i i i][x i x]}$ (Heckman, 2005; Fang Chao \& Huang Bin,2018). If considering non-economic factors, human capital investment will be restricted by time, energy and other conditions.

As an important part of human capital, cognitive ability is usually the focus of human capital investment. In existing studies, children's academic performance is often regarded as a proxy variable of cognitive ability, and education investment is often one of the main forms of children's human capital investment.

\subsection{Theory of "Quality Parents"}

Professor Mayer put forward the theory of "quality parents" in her book "What money can't buy: family income and children's life chances". The theory believes that low income will reduce the ability of parents to become good parents, not because poor families have no money to invest in 


\section{International Journal of Social Science and Economic Research}

ISSN: $2455-8834$

Volume:05, Issue:11 "November 2020"

children, but low income will reduce the quality of non-monetary investments, such as communication and interaction with children, future expectations, etc., and these will adversely affect the growth of the child ${ }^{[\mathrm{xx}]}$. Meyer pointed out that there are two versions of the "quality parents" theory, based on the parental stress theory and role-model theory.

Parental stress theory believes that poverty will bring pressure to children's parents, and will weaken their ability to support, sustain and participate in raising their children, and will also make parents more vulnerable to negative life events ${ }^{[x x i]}$ (McLoyd 1990). And this kind of parenting method can damage children's social and emotional development, limit their educational and social opportunities, and hinder their growth. This theory implies that if the government can transfer income to poor families, it will ease their pressure, so that they can improve their parenting methods, in order to achieve the result of raising the level of children's development.

The role model theory also emphasizes the interaction between parents and children, but not from the perspective of bearing pressure. The role model theory believes that because lowincome parents are at a relatively low social level, their values, behavior habits, etc. often have a certain gap with the success traits defined in mainstream culture, that is, "dysfunctional". Since children usually tend to imitate the values and behavior habits of their parents, the "dysfunctional" values and behavior habits of parents will be passed on to the children, that is, they will become the children's "bad" role models. This theory implies that it is difficult to improve their children's life opportunities in the short term if only increasing parents' income or directly investing in human capital for their children. On the contrary, the values, attitudes and behaviors of parents must be changed, and this process may require long-term efforts. It can be seen that the role model theory is mainly applicable to long-term poor families, while for shortterm poor families, the stress theory may be more applicable.

\section{Literature Review}

The influence of family on children's cognitive ability has been widely studied by scholars at home and abroad. Carlson \& Corcoran (2001) pointed out that family income and the quality of the family environment are particularly important for children's performance, and family income and mother's intellectual performance have a significant impact on children's cognitive ability test scores ${ }^{[x x i i]}$. Wu et al. (2014) pointed out that family economic status, parental participation and communication all have a significant impact on the future development of children, and pointed out that parents can strengthen cooperation with schools to make up for deficiencies and better promote child development ${ }^{[x x i i]}$.Li et al. (2017) analyzed the baseline data of the China Education Panel Survey (CEPS) and found that the higher the parents' educational level and 


\section{International Journal of Social Science and Economic Research}

ISSN: 2455-8834

Volume:05, Issue:11 "November 2020"

family socioeconomic status, the stronger the children's cognitive and non-cognitive abilities $^{[\mathrm{xxiv}]}$.Fang et al. (2019) analyzed the baseline data of the China Education Panel Survey (CEPS) and found that the higher the socioeconomic status of the family, the stronger the cognitive ability of the child. At the same time, the parents' care for the child and the child's own educational expectations for the future The development of cognitive ability also has a greater impact $^{[\mathrm{xxv}]}$.

But some scholars hold different views, Mayer(1997) Tracking investigation and research by analyzing the national income and expenditure dynamics of the United States (Panel Study of Income Dynamics, PSID) and the National Longitudinal Survey of Youth (NLSY) find The impact of income on children's performance is minimal, but she also pointed out that it does not mean that income is completely irrelevant, because most of the American children in her research sample have met their basic material needs, so they must also be considered Different research subjects can draw more true conclusions ${ }^{[\mathrm{xxvi}]}$. Chinese scholars Zhang and Li (2017) It is believed that family economic conditions have no significant impact on children's cognitive ability, and pointed out that this may be due to the nine-year compulsory education policy implemented by the government. At the same time, they found that parents' education and career expectations have a very significant positive impact on children's cognitive abilities ${ }^{\text {[xxvii] }}$.

In addition, the influence of the family on the children's future achievements has also attracted the attention of scholars for a long time. Duncan et al., (1998) pointed out that the economic situation of the family in the early childhood has a greater impact on the children's future achievements, and this impact is more obvious in low-income families ${ }^{\text {[xxviii] }}$. Hao \& BonsteadBruns (1998) believes that parents' educational expectations of their children are positively correlated with their children's achievements, and the interaction between parents and children can increase parents' expectations of their children in the future, thereby enhancing students' future achievements ${ }^{[\mathrm{xxix}]}$. Heckman (2006) believe that the early childhood growth environment will have an impact on its future, and early investment will greatly affect the productivity of later work ${ }^{[\mathrm{xxx}]}$.

\section{Data and Methods}

\subsection{Data Sources}

The data used in this article comes from the China Family Panel Studies (CFPS).The data is a nationwide follow-up survey data taken from 25 provinces, cities, and autonomous regions in China (except Hong Kong, Macao, Taiwan, Xinjiang, Tibet, Qinghai, Inner Mongolia, Ningxia, and Hainan). This article matches the family database, adult database, and child database in 


\section{International Journal of Social Science and Economic Research}

ISSN: $2455-8834$

Volume:05, Issue:11 "November 2020"

CFPS2016, and analyzes the impact of family resources on children's cognitive ability based on this.

\subsection{Variable Description}

The dependent variable of this article is children's cognitive ability, and the core independent variable is family resources. Family resources are divided into family economic resources and family non-economic resources. This article uses household annual income, total household assets and education expenditure as proxy variables to measure household economic resources. The variables of mother's cognitive ability, father's cognitive ability, parents' highest education, academic expectations, family environment and number of siblings are used as proxy variables to measure the family's non-economic resources. Children's grade, gender and household registration type are the control variables of this article.

In this article, children's cognitive abilities are derived from the weighted average of the children's sequence test results and memory test results. The sequence test results are 0-15 points. The memory test results are 0-10 points, I convert the sequence test results to 0-10 points. To facilitate the weighted average, the cognitive ability of the mother and the cognitive ability of the father are obtained by the same method. I take the logarithm of the annual family income, total family assets, and education expenditure in the family economic resources as the data used in the regression analysis. The highest educational qualifications of the parents in the family noneconomic resources are sorted according to the highest educational qualifications completed by the respondent in the personal questionnaire. 1 is below elementary school; 6 is elementary school; 9 is junior high school; 12 is high school; 15 is college; 16 is college bachelor degree; 19 is master degree and above. Academic expectations are the results of the children's expectations in the questionnaire. The family environment is determined by the average of the two responses of the interviewer's evaluations of the parental relationship, the children's education and the parents' active communication with the children. The specific options are as follows: 1 means strongly disagree; 2 means disagree; 3 means neutral; 4 means agree; 5 means fully agree. The number of siblings is the number of children in the family. Among the control variables, the children's grades are from 1st to 12th grade, that is, from grade 1 to grade 3 in high school; for gender, assign a value of 1 for boys and 0 for girls; meanwhile, assign a value of 1 to agricultural household registration for children, and 0 to non-agricultural household registration. 
International Journal of Social Science and Economic Research

ISSN: 2455-8834

Volume:05, Issue:11 "November 2020"

\section{Table 1 Definition of main variables and sources of data information}

\begin{tabular}{|c|c|}
\hline Variable Definitions & The Data Shows \\
\hline Children's Cognitive Ability & $\begin{array}{l}\text { Weighted average of children's sequence test results and } \\
\text { memory test results }\end{array}$ \\
\hline Family Income & Logarithm of total income (yuan) in the past 12 months \\
\hline Total Family Assets & Logarithm of family net assets (yuan) \\
\hline Education Expenses & $\begin{array}{l}\text { Logarithm of education and training expenditures (yuan) in } \\
\text { the past } 12 \text { months }\end{array}$ \\
\hline Mother's Cognitive Ability & $\begin{array}{l}\text { Weighted average of maternal sequence test results and } \\
\text { memory test results }\end{array}$ \\
\hline Father's Cognitive Ability & $\begin{array}{l}\text { The weighted average of the father's sequence test results and } \\
\text { memory test results }\end{array}$ \\
\hline Parent's Highest Education & $\begin{array}{l}\text { The highest degree completed by the respondent in the } \\
\text { individual questionnaire; } 1=\text { below elementary school; } \\
6=\text { primary school; } 9=\text { junior high school; } 12=\text { high school; } \\
15=\text { junior college; } 16=\text { =bachelor degree; } 19=\text { master's degree } \\
\text { and above }\end{array}$ \\
\hline Academic Expectation & What do you expect your children's grades \\
\hline Family Environment & $\begin{array}{l}\text { The mean value of parents' concern about children's } \\
\text { education and parents' communication with children } \\
\text { (interviewer's evaluation) }\end{array}$ \\
\hline Number of Siblings & Number of children in the family \\
\hline Grade & What grade is the child in \\
\hline Gender & $1=$ boy; $0=$ girl \\
\hline Household Registration & $\begin{array}{l}1=\text { Agricultural household registration; } 0=\text { Non-agricultural } \\
\text { household registration }\end{array}$ \\
\hline
\end{tabular}

\subsection{Descriptive statistics of main variables}

In this paper, the family database, adult database, and child database are matched, and missing values and outliers are deleted. The final sample size is 1061. Table 2 shows the descriptive statistical results of each variable. It can be seen from Table 2 that the maximum value of the dependent variable children's cognitive ability (including sequence performance and memory 


\section{International Journal of Social Science and Economic Research}

ISSN: $2455-8834$

Volume:05, Issue:11 "November 2020"

performance) is 10 points, and the minimum value is 0 points. Children's average cognition ability is 6.238 points. The three variables of family economic resources in the core independent variables: family annual income, total family assets, and education expenditure, are taken logarithms for statistics. Among the core independent variables, family non-economic resources are six variables. The maximum value of the mother's cognitive ability is 9.333 points, the minimum value is 0 points, and the average value is 4.859 points; the maximum value of the father's cognitive ability is 10 points and the minimum It is 0 points and the average is 5.073 points. It can be seen that the average cognitive ability of fathers is higher than that of mothers. The maximum of the parents' highest education is 19 , the minimum is 1 , and the average is 8.549, indicating that the minimum education is below elementary school, and the highest education is master's degree and above. The academic expectation in the descriptive form has a maximum score of 100 points, a minimum score of 60 points, and an average of 89.546 points. The highest score for family environment is 5 points, the lowest score is 1 point, and the average is 3.759 points. The maximum number of siblings is 7 , the minimum is 1 , and the average is 2.337. The grades of the children in this data are grades $1-12$, indicating that the covered student group is from primary school grade 1 to high school grade 3 . The mean value of gender is 0.568 , indicating that the proportion of boys in this data is relatively high. The average household registration type is 0.785 , indicating that the proportion of agricultural household registration in the sample is more important than non-agricultural household registration.

Table 2 Descriptive Statistics of Each Variable

\begin{tabular}{cccccc}
\hline Variable & Average & Standard deviation & Max & Min & Sample size \\
\hline Children's Cognitive Ability & 6.238 & 1.648 & 10 & 0 & 1061 \\
Family Economic Resources & & & & & 1061 \\
Family Income & 10.580 & 0.961 & 14.509 & 5.298 & 1061 \\
Total Family Assets & 12.245 & 2.246 & 16.411 & 0 & 1061 \\
Education Expenses & 6.975 & 2.170 & 11.567 & 0 & 1061 \\
Family Non-economic resources & & & & & 1061 \\
Mother's Cognitive Ability & 4.859 & 1.920 & 9.333 & 0 & 1061 \\
Father's Cognitive Ability & 5.073 & 1.828 & 10 & 0 & 1061 \\
Parent's Highest Education & 8.549 & 3.841 & 19 & 1 & 1061 \\
Academic Expectations & 89.546 & 9.304 & 100 & 60 & 1 \\
Family Environment & 3.759 & 0.769 & 5 & 7 & 1 \\
Number of Siblings & 2.337 & 1.129 & & & 1061
\end{tabular}




\section{International Journal of Social Science and Economic Research}

ISSN: $2455-8834$

Volume:05, Issue:11 "November 2020"

$\begin{array}{cccccr}\text { Grade } & 6.038 & 1.844 & 12 & 1 & 1061 \\ \text { Gender } & 0.568 & 0.496 & 1 & 0 & 1061 \\ \text { Household Registration } & 0.785 & 0.411 & 1 & 0 & 1061\end{array}$

\subsection{Model Setting}

This article studies the impact of family resources on children's cognitive abilities. Equation (1) is the benchmark estimation equation of this article:

$$
\operatorname{Ccog}=\alpha+\beta \text { Fres }+\gamma \mathrm{X}+\varepsilon
$$

In equation (1), Cog is the child's cognitive ability score; Fres is the family resource; $\beta$ is the coefficient of influence of family resources on the child's cognitive ability; the control variable $\mathrm{X}$ includes the child's individual characteristics (grade, gender, household registration type); $\varepsilon$ Is a random error term. Family resources Fres include family economic resources (family annual income, total family assets, education expenditure) and family non-economic resources (maternal cognitive ability, father cognitive ability, parents' highest education, academic expectations, family environment, number of siblings).

\section{Data Analysis Results}

Table 3 shows the regression analysis of the impact of family resources on children's cognitive ability. The first column is the regression without considering the non-economic resources of the family. It can be seen that the annual family income is significantly positively correlated at the $1 \%$ confidence level, indicating that the higher the annual family income, the higher the cognitive ability of children. And education expenditure is also significantly positively correlated at the $1 \%$ confidence level, indicating that the higher the education expenditure, the higher the children's cognitive ability. The greater the total family assets, the higher the children's cognitive ability, but this relationship is not significant. At the same time, grade and gender are significantly positively correlated at the $1 \%$ confidence level, indicating that the higher the grade, the higher the cognitive ability of children, and the greater the likelihood that boys have cognitive abilities compared to girls. Household Registration is significantly negatively correlated at the $1 \%$ confidence level, indicating that urban children have higher cognitive abilities than children with Agricultural Household Registration.

The second column is the regression without considering the family's economic resources. It can be seen that in the family's non-economic resources, the mother's cognitive ability, father's cognitive ability, academic expectations, and family environment are all significant at the $1 \%$ confidence level The positive correlation indicates that the higher the cognitive ability of the mother, the cognitive ability of the father, the academic expectation, and the family environment, 


\section{International Journal of Social Science and Economic Research}

ISSN: $2455-8834$

Volume:05, Issue:11 "November 2020"

the higher the cognitive ability of the family children. The cognitive ability of children with more siblings may be higher, but this relationship is not significant. In addition, grade and gender are significantly positively correlated at the $1 \%$ confidence level, and Household Registration is significantly negatively correlated at the $5 \%$ confidence level, indicating that children with agricultural Household Registration have relatively poorer overall cognitive abilities than children with non-agricultural Household Registration.

The third column is the regression without considering education expenses. It can be seen that the annual household income is significantly positively correlated at the $10 \%$ confidence level, indicating that the higher the annual household income, the higher the cognitive ability of children. At the same time, the cognitive ability of the mother and the cognitive ability of the father are significantly positively correlated at the $1 \%$ confidence level, indicating that the higher the cognitive ability of the mother and the father, the higher the cognitive ability of the child. Academic expectations and family environment are also significantly positively correlated at the $1 \%$ confidence level, indicating that the higher the parents' academic expectations and family environment scores for children, the stronger the children's cognitive ability.

The fourth column is the regression based on the family economic resources and non-economic resources. It can be seen that the more the family's annual income and education expenditure, the higher the children's cognitive ability, but this relationship is not significant. The mother's cognitive abilities, father's cognitive abilities, academic expectations, and family environment in family non-economic resources are all significantly positively correlated at the $1 \%$ confidence level, indicating that mother's cognitive abilities, father's cognitive abilities, academic expectations, and family environment The higher the score, the higher the cognitive ability of children in families. Grade and gender are significantly positively correlated at the $1 \%$ confidence level, which is consistent with the conclusions drawn in the above three columns. At the same time, the Household Registration type is significantly negatively correlated at the $10 \%$ confidence level.

Table 3 Benchmark Regression

\begin{tabular}{|c|c|c|c|}
\hline & $(2)$ & (3) & (4) \\
\hline \multirow[t]{2}{*}{ Family Income } & $0.198^{\text {**** }}$ & $0.094^{*}$ & 0.079 \\
\hline & $(3.48)$ & $(1.75)$ & $(1.42)$ \\
\hline \multirow[t]{2}{*}{ Total Family Assets } & 0.005 & -0.000 & -0.001 \\
\hline & $(0.21)$ & $(-0.00)$ & $(-0.06)$ \\
\hline Education Expenses & $0.075^{* * *}$ & & 0.029 \\
\hline
\end{tabular}


International Journal of Social Science and Economic Research

ISSN: 2455-8834

Volume:05, Issue:11 "November 2020"

(3.11)

Mother's Cognitive Ability

$0.180^{* * * *}$

$0.176^{* * *}$

$0.175^{* * *}$

(6.77)

(6.60)

(6.54)

Father's Cognitive Ability

$0.134^{* * *}$

$0.128^{\text {*** }}$

$0.128^{* * *}$

$(4.82)$

(4.55)

(4.56)

Parent's Highest Education

0.001

$-0.005$

$-0.006$

(0.04)

$(-0.34)$

$(-0.40)$

Academic Expectations

$0.025^{* * *}$

$0.024^{* * * *}$

$0.024^{* * *}$

(5.08)

(4.99)

(4.76)

Family Environment

$0.185^{* * *}$

$0.188^{* * *}$

$0.182^{* * * *}$

(3.07)

(3.11)

(3.00)

Number of Siblings

0.000

$-0.001$

0.001

(0.01)

$(-0.02)$

(0.02)

Grade

$0.224^{* * *}$

$0.242^{* * *}$

$0.240^{* * * *}$

$0.234^{* * *}$

(8.60)

(9.92)

(9.85)

(9.41)

Gender

$0.298^{* * *}$

$0.303^{* * *}$

$0.299^{* * *}$

$0.297^{* * *}$

(3.14)

(3.38)

(3.34)

(3.31)

Household Registration

$-0.449^{* * *}$

$-0.292^{* *}$

$-0.261^{* * *}$

$-0.243^{*}$

$(-3.69)$

$(-2.36)$

$(-2.09)$

$(-1.93)$

_cons

$2.402^{* * * *}$

0.348

$-0.529$

$-0.414$

(4.01)

(0.64)

$(-0.73)$

$(-0.57)$

\section{$\mathrm{N}$}

1061

1061

1061

1061

adj. R2

0.141

0.245

0.246

0.247

Note: $* * * \mathrm{p}<0.01, * * \mathrm{p}<0.05, * \mathrm{p}<0.1$

\section{Heterogeneity Analysis}

In order to further explore the impact of family resources on the cognitive abilities of children of different grades, this article analyzes the heterogeneity of children in different grades. The sample is divided into four parts, namely primary school 1-3, primary school 4-6, junior high school group, and high school group.

Table 4 shows the regression results of the family resources of the primary 1-3 grade group on the children's cognitive ability, with a sample size of 71 people. The first column in Table 4 is the regression without considering the non-economic resources of the family. It can be seen that 
education expenditure is significantly positively correlated at the $1 \%$ confidence level, indicating that the higher the education expenditure, the recognition of children in grades 1-3 The higher the knowledge ability. At the same time, the gender of children is significantly positively correlated at the $10 \%$ executive level, indicating that boys have higher cognitive abilities than girls. The consistent conclusion drawn in the second, third, and fourth columns is that the mother's cognitive ability is significantly positively correlated at the $5 \%$ confidence level, indicating that the higher the mother's cognitive ability, the higher the child's cognitive ability. In addition, in the fourth column, education expenditure is significantly positively correlated at the $5 \%$ confidence level.

Table 4 Regression results of family resources on children's cognitive ability (grades 1-3)

\begin{tabular}{|c|c|c|c|c|}
\hline & (1) & (2) & (3) & (4) \\
\hline \multirow[t]{2}{*}{ Family Income } & -0.009 & & -0.138 & -0.249 \\
\hline & $(-0.03)$ & & $(-0.44)$ & $(-0.79)$ \\
\hline \multirow[t]{2}{*}{ Total Family Assets } & -0.140 & & -0.040 & -0.072 \\
\hline & $(-1.34)$ & & $(-0.36)$ & $(-0.67)$ \\
\hline \multirow[t]{2}{*}{ Education Expenses } & $0.372^{* * *}$ & & & $0.252^{* *}$ \\
\hline & $(3.36)$ & & & $(2.10)$ \\
\hline \multirow[t]{2}{*}{ Mother's Cognitive Ability } & & $0.273^{* *}$ & $0.270^{* *}$ & $0.260^{* *}$ \\
\hline & & $(2.26)$ & $(2.21)$ & $(2.19)$ \\
\hline \multirow[t]{2}{*}{ Father's Cognitive Ability } & & 0.120 & 0.136 & 0.116 \\
\hline & & $(0.91)$ & $(1.02)$ & $(0.89)$ \\
\hline \multirow[t]{2}{*}{ Parent's Highest Education } & & 0.048 & 0.067 & 0.045 \\
\hline & & $(0.80)$ & $(1.04)$ & $(0.71)$ \\
\hline \multirow[t]{2}{*}{ Academic Expectations } & & 0.028 & 0.028 & 0.017 \\
\hline & & $(1.24)$ & $(1.17)$ & $(0.71)$ \\
\hline \multirow[t]{2}{*}{ Family Environment } & & 0.355 & 0.340 & 0.177 \\
\hline & & $(1.24)$ & $(1.17)$ & $(0.60)$ \\
\hline \multirow[t]{2}{*}{ Number of Siblings } & & 0.173 & 0.218 & 0.206 \\
\hline & & $(0.77)$ & $(0.94)$ & $(0.91)$ \\
\hline \multirow[t]{2}{*}{ Gender } & $0.819^{*}$ & 0.659 & $0.740^{*}$ & $0.840^{* *}$ \\
\hline & $(1.95)$ & $(1.61)$ & $(1.76)$ & $(2.04)$ \\
\hline \multirow[t]{2}{*}{ Household Registration } & -0.018 & -0.350 & -0.412 & -0.081 \\
\hline & $(-0.03)$ & $(-0.53)$ & $(-0.60)$ & $(-0.12)$ \\
\hline
\end{tabular}


International Journal of Social Science and Economic Research

ISSN: 2455-8834

Volume:05, Issue:11 "November 2020"

\begin{tabular}{lllll} 
_cons & 4.118 & -1.292 & 0.328 & 1.844 \\
& $(1.54)$ & $(-0.53)$ & $(0.10)$ & $(0.57)$ \\
\hline $\mathrm{N}$ & 71 & 71 & 71 & 71 \\
adj. R2 & 0.159 & 0.196 & 0.181 & 0.225
\end{tabular}

Note: $* * * \mathrm{p}<0.01, * * \mathrm{p}<0.05, * \mathrm{p}<0.1$.

Table 5 shows the regression results of the family resources of the 4-6 grade primary school group on the children's cognitive ability, with a sample size of 549 people. The first column is the regression without considering the non-economic resources of the family. It can be seen that the annual family income is significantly positively correlated at the $1 \%$ confidence level, indicating that the higher the annual family income, the stronger the cognitive ability of children. Education expenditure is significantly positively correlated at the 5\% confidence level, indicating that the higher the education expenditure, the stronger the children's cognitive ability. The second, third, and fourth columns of maternal cognitive ability, father's cognitive ability, academic expectations, and family environment are all significantly positively correlated at the $1 \%$ confidence level, which is consistent with the conclusions drawn in Table 3 of the regression analysis, Indicating that the higher the scores of parents' cognitive ability, academic expectations and family environment, the higher the children's cognitive ability. The genders in columns 1-4 are all significantly positively correlated at the $1 \%$ confidence level, indicating that overall, boys have higher cognitive abilities than girls.

Table 5 Regression Results of Family Resources on Children's Cognitive Ability (Grade 4-6)

\begin{tabular}{|c|c|c|c|c|}
\hline & (1) & (2) & (3) & (4) \\
\hline \multirow[t]{2}{*}{ Family Income } & $0.260^{* * *}$ & & $0.187^{* *}$ & $0.166^{* *}$ \\
\hline & $(3.35)$ & & $(2.47)$ & $(2.13)$ \\
\hline \multirow[t]{2}{*}{ Total Family Assets } & 0.004 & & -0.010 & -0.010 \\
\hline & $(0.14)$ & & $(-0.34)$ & $(-0.35)$ \\
\hline \multirow[t]{2}{*}{ Education Expenses } & $0.071^{* *}$ & & & 0.031 \\
\hline & $(2.26)$ & & & $(1.02)$ \\
\hline \multirow[t]{2}{*}{ Mother's Cognitive Ability } & & $0.154^{* * *}$ & $0.147^{* * *}$ & $0.146^{* * *}$ \\
\hline & & $(4.02)$ & $(3.83)$ & $(3.80)$ \\
\hline \multirow[t]{2}{*}{ Father's Cognitive Ability } & & $0.141^{* * *}$ & $0.125^{* * *}$ & $0.126^{* * *}$ \\
\hline & & $(3.59)$ & $(3.16)$ & $(3.19)$ \\
\hline Parent's Highest Education & & -0.020 & -0.033 & -0.033 \\
\hline www.ijsser.org & \multicolumn{3}{|c|}{ Copyright (C IJSSER 2020, All rights reserved } & Page 3304 \\
\hline
\end{tabular}


International Journal of Social Science and Economic Research

ISSN: 2455-8834

Volume:05, Issue:11 "November 2020"

\begin{tabular}{|c|c|c|c|c|}
\hline & & $(-0.94)$ & $(-1.51)$ & $(-1.51)$ \\
\hline \multirow[t]{2}{*}{ Academic Expectations } & & $0.032^{* * *}$ & $0.031^{* * *}$ & $0.030^{* * *}$ \\
\hline & & $(4.03)$ & (3.93) & $(3.73)$ \\
\hline \multirow[t]{2}{*}{ Family Environment } & & $0.234^{* * *}$ & $0.238^{* * *}$ & $0.229^{* * *}$ \\
\hline & & $(2.76)$ & $(2.81)$ & $(2.70)$ \\
\hline \multirow[t]{2}{*}{ Number of Siblings } & & -0.008 & -0.015 & -0.010 \\
\hline & & $(-0.13)$ & $(-0.26)$ & $(-0.17)$ \\
\hline \multirow[t]{2}{*}{ Gender } & $0.371^{* * *}$ & $0.378^{* * *}$ & $0.382^{* * *}$ & $0.383^{* * *}$ \\
\hline & $(2.77)$ & $(2.96)$ & $(3.00)$ & $(3.01)$ \\
\hline \multirow[t]{2}{*}{ Household Registration } & -0.204 & -0.170 & -0.115 & -0.091 \\
\hline & $(-1.17)$ & $(-0.94)$ & $(-0.64)$ & $(-0.50)$ \\
\hline \multirow[t]{2}{*}{ _cons } & $2.694^{* * *}$ & 0.917 & -0.674 & -0.555 \\
\hline & $(3.29)$ & $(1.17)$ & $(-0.65)$ & $(-0.54)$ \\
\hline $\mathrm{N}$ & 549 & 549 & 549 & 549 \\
\hline adj. R2 & 0.063 & 0.157 & 0.164 & 0.164 \\
\hline
\end{tabular}

Note: $* * * \mathrm{p}<0.01, * * \mathrm{p}<0.05,{ }^{*} \mathrm{p}<0.1$.

Table 6 shows the regression results of family resources in the junior high school group (grades 7-9) on children's cognitive abilities, with a sample size of 426 people. In columns $2-4$, the mother's cognitive ability is significantly positively correlated at the $1 \%$ confidence level, indicating that the higher the mother's cognitive ability, the higher the child's cognitive ability; academic expectations are significantly positively correlated at the $5 \%$ confidence level, The results are also consistent with the regression results in Table 3.

Table 6 Regression results of family resources on children's cognitive abilities (junior high school group (grades 7-9))

\begin{tabular}{lllll}
\hline & $(1)$ & $(2)$ & $(3)$ & $(4)$ \\
\hline Family Income & 0.127 & 0.026 & 0.023 \\
Total Family Assets & $(1.44)$ & $0.31)$ & $(0.27)$ \\
& 0.036 & 0.036 & 0.035 \\
Education Expenses & $(1.00)$ & $(1.06)$ & $(1.03)$ \\
& 0.059 & & 0.006 \\
Mother's Cognitive Ability & $(1.43)$ & $0.194^{* * *}$ & $0.194^{* * *}$ & $0.193^{* * *}$ \\
\hline \hline
\end{tabular}


International Journal of Social Science and Economic Research

ISSN: 2455-8834

Volume:05, Issue:11 "November 2020"

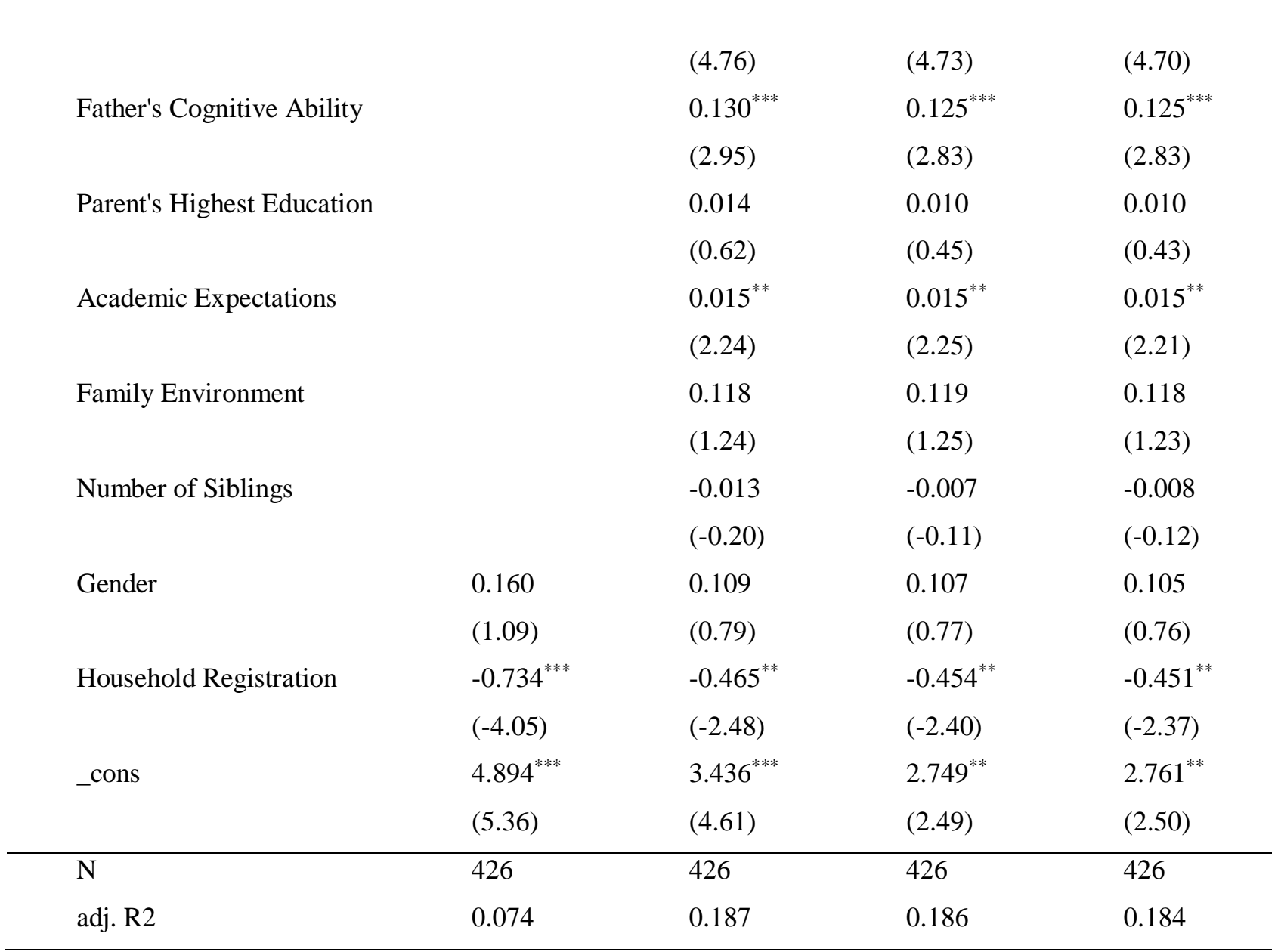

Note: $* * * \mathrm{p}<0.01,{ }^{* *} \mathrm{p}<0.05,{ }^{*} \mathrm{p}<0.1$.

This article also analyzed high school students (grades 10-12). The sample size is 15 people. Because the sample size is too small, the regression results are not representative, so the analysis table is included in the appendix for reference only. Through the analysis of heterogeneity by grade, it can be seen that in the lower grades, the investment in education has a significant effect on the improvement of cognitive ability, and as the grade rises, the effect of education expenditure on the improvement of children's cognitive ability It gradually becomes insignificant.

\section{Conclusion and Discussion}

Through the above empirical analysis, it can be seen that, without considering the family's noneconomic resources, the higher the family's annual income and education expenditure in the family's economic resources, the stronger the children's cognitive ability. However, considering family economic and non-economic resources, the unanimous conclusion is that, compared with family economic resources, family non-economic resources have a more significant impact on 


\section{International Journal of Social Science and Economic Research}

ISSN: $2455-8834$

Volume:05, Issue:11 "November 2020"

children's cognitive abilities, indicating that family non-economic resources have on children's cognitive abilities The impact is more effective.

And through data analysis, we can see that the higher the parents' academic expectations of children, the higher the children's cognitive ability, and the family environment score also significantly affects children's cognitive ability. In addition, the overall cognitive ability of boys is higher than that of girls. Finally, the overall cognitive ability of children with non-agricultural Household Registration is higher than that of children with agricultural Household Registration, indicating that there is still a certain gap in education among urban and rural children.

In response to the above conclusions, I make the following suggestions: First, parents should encourage their children more in their daily lives, fully respect their children, and have confidence in their growth. This can encourage children to earnestly learn knowledge and correct their attitudes towards life. At the same time, parents should reduce unnecessary complaints about their children and reduce their physical and mental burden so that they can devote themselves to learning.

Secondly, the family environment score evaluated by the interviewer is obtained by the interviewer during the interview process according to the degree of parental care for the child's education and the degree of parental initiative to communicate with the child. This shows that the communication between parents and children can play a certain role in improving children's cognitive ability. The so-called "teaching by words and deeds", parents are the role models for students. Parents' performance in front of their children will have a subtle impact on children's daily life and learning, and will also have an impact on the improvement of children's cognitive ability.

In addition, in personal characteristics, the higher the grade, the higher the children's cognitive ability, which shows that normal learning and accumulation are also very important. Parents don't need to worry too much, and they don't need to increase the student's academic pressure. At the same time, it can be seen that the cognitive ability of boys is higher than that of girls as a whole, so the parents of girls' families should pay more attention to and pay more attention to the students' physical and mental development and learning situation to help their cognitive ability.

Finally, we should focus on improving the education awareness of children in rural families, especially in the early stages of children's growth, in order to avoid the widening of the gap in child development between urban and rural areas. 
International Journal of Social Science and Economic Research

ISSN: 2455-8834

Volume:05, Issue:11 "November 2020"

\section{Appendix}

Table A Regression results of the influence of family resources on children's cognitive ability (high school group (grade 10-12))

\begin{tabular}{|c|c|c|c|c|}
\hline & (1) & (2) & (3) & (4) \\
\hline \multirow[t]{2}{*}{ Family Income } & 0.711 & & $6.461^{* *}$ & $5.941^{*}$ \\
\hline & (1.13) & & $(3.33)$ & $(2.49)$ \\
\hline \multirow[t]{2}{*}{ Total Family Assets } & 0.600 & & -0.165 & 0.053 \\
\hline & $(1.63)$ & & $(-0.92)$ & $(0.11)$ \\
\hline \multirow[t]{2}{*}{ Education Expenses } & $0.443^{*}$ & & & 0.216 \\
\hline & $(2.19)$ & & & $(0.50)$ \\
\hline \multirow[t]{2}{*}{ Mother's Cognitive Ability } & & 0.289 & $0.892^{* *}$ & $0.852^{*}$ \\
\hline & & $(1.06)$ & $(3.53)$ & $(2.93)$ \\
\hline \multirow[t]{2}{*}{ Father's Cognitive Ability } & & -0.258 & $1.829^{*}$ & $1.852^{*}$ \\
\hline & & $(-0.60)$ & $(2.68)$ & $(2.44)$ \\
\hline \multirow[t]{2}{*}{ Parent's Highest Education } & & 0.149 & $-1.407^{* *}$ & $-1.334^{*}$ \\
\hline & & $(0.77)$ & $(-2.91)$ & $(-2.41)$ \\
\hline \multirow[t]{2}{*}{ Academic Expectations } & & 0.099 & -0.138 & -0.170 \\
\hline & & $(1.78)$ & $(-1.74)$ & $(-1.56)$ \\
\hline \multirow[t]{2}{*}{ Family Environment } & & 0.101 & $-1.301^{*}$ & -1.002 \\
\hline & & $(0.23)$ & $(-2.45)$ & $(-1.20)$ \\
\hline \multirow[t]{2}{*}{ Number of Siblings } & & $1.891^{*}$ & -0.791 & -1.202 \\
\hline & & $(2.17)$ & $(-0.81)$ & $(-0.89)$ \\
\hline \multirow[t]{2}{*}{ Gender } & -0.518 & -1.315 & $5.706^{*}$ & 4.983 \\
\hline & $(-0.53)$ & $(-1.15)$ & $(2.56)$ & $(1.75)$ \\
\hline \multirow[t]{2}{*}{ Household Registration } & 0.269 & -3.224 & $8.292^{*}$ & 8.718 \\
\hline & $(0.28)$ & $(-1.72)$ & $(2.27)$ & $(2.11)$ \\
\hline \multirow[t]{2}{*}{ _cons } & $-11.542^{*}$ & -4.568 & $-49.858^{* *}$ & $-46.793^{*}$ \\
\hline & $(-2.14)$ & $(-1.03)$ & $(-3.55)$ & $(-2.80)$ \\
\hline $\mathrm{N}$ & 15 & 15 & 15 & 15 \\
\hline adj. R2 & 0.515 & 0.613 & 0.847 & 0.812 \\
\hline
\end{tabular}

Note: $* * * \mathrm{p}<0.01, * * \mathrm{p}<0.05, * \mathrm{p}<0.1$. 
International Journal of Social Science and Economic Research

ISSN: 2455-8834

Volume:05, Issue:11 "November 2020"

\section{References}

[i] Batty G D, Mortensen E L, Osler M. Childhood IQ in relation to later psychiatric disorder: evidence from a Danish birth cohort study[J]. The British Journal of Psychiatry, 2005, 187(2): 180-181.

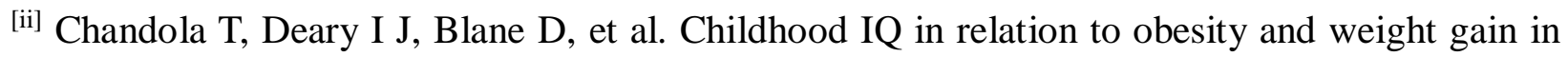
adult life: the National Child Development (1958) Study[J]. International journal of obesity, 2006, 30(9): 1422-1432.

[iii] Batty G D, Deary I J, Schoon I, et al. Mental ability across childhood in relation to risk factors for premature mortality in adult life: the 1970 British Cohort Study[J]. Journal of Epidemiology \& Community Health, 2007, 61(11): 997-1003.

[iv] Thienpont K, Verleye G. Cognitive ability and occupational status in a British cohort[J]. Journal of Biosocial Science, 2004, 36(3): 333.

${ }^{[v]}$ Irwing P, Lynn R. The relation between childhood IQ and income in middle age[J]. Journal of Social Political and Economic Studies, 2006, 31(2): 191.

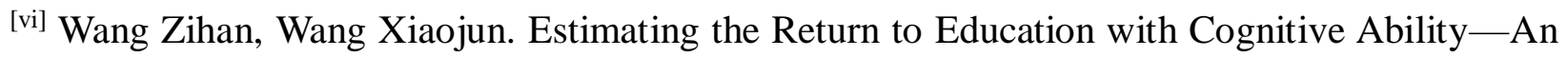
Empirical Analysis Based on CHIP 2007 Survey Data[J].Education \& Economy, 2016(01):39$46+74$.

[vii] Plomin R. Genetics and general cognitive ability[J]. Nature, 1999, 402(6761): C25-C29.

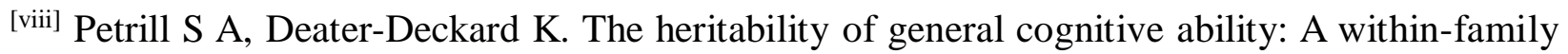
adoption design[J]. Intelligence, 2004, 32(4): 403-409.

${ }^{[i x]}$ Harris J R. The nurture assumption: Why children turn out the way they do[M]. Simon and Schuster, 2011.

[x] Gagné L G. Parental work, child-care use and young children's cognitive outcomes[M]. Statistics Canada, 2003.

[xi] Schoon I, Jones E, Cheng H, et al. Family hardship, family instability, and cognitive development[J]. J Epidemiol Community Health, 2012, 66(8): 716-722.

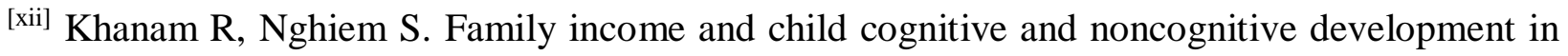


International Journal of Social Science and Economic Research

ISSN: 2455-8834

Volume:05, Issue:11 "November 2020"

Australia: Does money matter?[J]. Demography, 2016, 53(3): 597-621.

[xiii] Blau D M. The effect of income on child development[J]. Review of Economics and Statistics, 1999, 81(2): 261-276.

[xiv] Violato M, Petrou S, Gray R, et al. Family income and child cognitive and behavioural development in the United Kingdom: does money matter?[J]. Health economics, 2011, 20(10): 1201-1225.

${ }^{[x v]}$ Schultz T W. Investment in human capital[J]. The American economic review, 1961: 1-17.

${ }^{[x v i]}$ Heckman J J. Policies to foster human capital[J]. Research in economics, 2000, 54(1): 3-56.

[xvii] Becker G S. Human capital: A theoretical and empirical analysis, with special reference to education[M]. University of Chicago press, 2009.

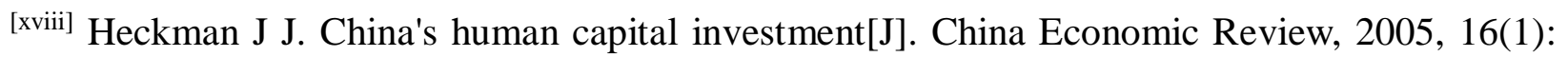
50-70.

${ }^{[x i x]}$ Fang Chao, Huang Bin.Influence of Family Human Capital Investment on Children's Academic Achievement: Analysis of Multilevel Liner Model Based on CEPS Tracking Data [J].Journal of Anhui Normal University(Hum.\& Soc.Sci.),2018,46(02):116-124.

${ }^{[x x]}$ Mayer S E. What money can't buy: Family income and children's life chances[M]. Harvard University Press, 1997.

[xxi] McLoyd V C. The impact of economic hardship on Black families and children: Psychological distress, parenting, and socioemotional development[J]. Child development, 1990, 61(2): 311-346.

[xxii] Carlson M J, Corcoran M E. Family structure and children's behavioral and cognitive outcomes[J]. Journal of marriage and family, 2001, 63(3): 779-792.

[xxiii] Wu Chonghan, Zhang Jun,Wang Meiwu.The power of parent participation: family capital, home-school cooperation and children's growth[J].Educational Academic Monthly, 2014 (03): $15-27$.

${ }^{[x x i v]} \mathrm{Li}$ Li,Zhao Wenlong.Research on the influence of family background and cultural capital on cognitive and non-cognitive abilities[J].Dongyue Tribune,2017,38(04):142-150. 
${ }^{[x x v]}$ Fang Guangbao,Hou Yi.How does family socioeconomic status affect the development of junior high school students' cognitive ability[J].Global Education,2019,48(09):68-76.

[xxvi] Mayer S E. What money can't buy: Family income and children's life chances[M]. Harvard University Press, 1997.

[xxvii] Zhang Qilin,Li Peng.Family background, parental expectations and children's cognitive abilities: empirical evidence from the China Education Tracking Survey[J].Journal of Wuhan University of Technology (Social Sciences Edition),2017,30(03):97-106.

[xxviii] Duncan G J, Yeung W J, Brooks-Gunn J, et al. How much does childhood poverty affect the life chances of children?[J]. American sociological review, 1998: 406-423.

[xxix] Hao L, Bonstead-Bruns M. Parent-child differences in educational expectations and the academic achievement of immigrant and native students[J]. Sociology of education, 1998: 175198.

${ }^{[\mathrm{xxx}]}$ Heckman J J. Skill formation and the economics of investing in disadvantaged children[J]. Science, 2006, 312(5782): 1900-1902. 